Revista Eletrônica de Direito Processual - REDP.

Rio de Janeiro. Ano 15. Volume 22. Número 3. Setembro a Dezembro de 2021

Periódico Quadrimestral da Pós-Graduação Stricto Sensu em Direito Processual da UERJ

Patrono: José Carlos Barbosa Moreira (in mem.). ISSN 1982-7636. pp. 82-102

www.redp.uerj.br

\title{
JURISDIÇÃO SUSTENTÁVEL E A (IM)POSSIBILIDADE DA REVISÃO EM \\ DECISÃO ADMINISTRATIVA DA GRATUIDADE DOS EMOLUMENTOS \\ EXTRAJUDICIAIS CONCEDIDA PELO PODER JUDICIÁRIO'²
}

\section{SUSTAINABLE JURISDICTION AND THE (IM) POSSIBILITY OF REVISION IN \\ ADMINISTRATIVE DECISION ON THE GRATUITY OF EXTRAJUDICIAL \\ EMOLUMENTS GRANTED BY JUDICIAL POWER}

Antonieta Caetano Gonçalves

Doutoranda em Meio Ambiente pela Dom Helder Câmara e mestra em Instituições Sociais, Direito e Democracia. Graduação em Direito pela Pontifícia Universidade Católica de Minas Gerais (2014), graduação em Ciências Contábeis pelo Centro Universitário Newton Paiva (1989). ORCID: http://orcid.org/0000-0001-56239318. Currículo Lattes: http://lattes.cnpq.br/1317347950255642. Belo Horizonte/MG. E-mail: acmarins@bol.com.br.

Magno Federici Gomes Estágio Pós-doutoral em Direito Público e Educação pela Universidade Nova de Lisboa-Portugal (Bolsa CAPES/BEX 3642/07-0). Estágios Pós-doutorais em Direito Civil e Processual Civil, Doutor em Direito e Mestre em Direito Processual, pela Universidad de Deusto-Espanha (Bolsa da Cátedra UNESCO e do Gobierno Vasco-Espanha). Mestre em Educação pela PUC Minas. Professor do Doutorado e Mestrado Acadêmico em Direito Ambiental e

\footnotetext{
${ }^{1}$ Artigo recebido em 27/04/2021 e aprovado em 23/07/2021.

2 Trabalho financiado pelo Projeto Edital $n^{\circ}$ 03/2019 de Incentivo à Pesquisa da Escola Superior Dom Helder Câmara, resultante dos Grupos de Pesquisas (CNPQ): Regulação Ambiental da Atividade Econômica Sustentável (REGA), NEGESP, Metamorfose Jurídica e CEDIS (FCT-PT).
} 
Revista Eletrônica de Direito Processual - REDP.

Rio de Janeiro. Ano 15. Volume 22. Número 3. Setembro a Dezembro de 2021

Periódico Quadrimestral da Pós-Graduação Stricto Sensu em Direito Processual da UERJ

Patrono: José Carlos Barbosa Moreira (in mem.). ISSN 1982-7636. pp. 82-102

www.redp.uerj.br

Desenvolvimento Sustentável na Escola Superior Dom

Helder Câmara. Professor Titular licenciado da Faculdade de

Direito Arnaldo Janssen. Advogado Sócio do Escritório

Moraes \& Federici Advocacia Associada. Líder do Grupo de

Pesquisa: Regulação Ambiental da Atividade Econômica

Sustentável (REGA)/CNPQ-BRA e integrante dos grupos:

Centro de Investigação \& Desenvolvimento sobre Direito e

Sociedade (CEDIS)/FCT-PT, Núcleo de Estudos sobre

Gestão de Políticas Públicas (NEGESP)/CNPQ-BRA e

Metamorfose Jurídica/CNPQ-BRA. ORCID:

http://orcid.org/0000-0002-4711-5310. Currículo Lattes:

http://lattes.cnpq.br/1638327245727283. Belo

Horizonte/MG. E-mail: magnofederici@gmail.com.

RESUMO: Garantias constitucionais de acesso ao Judiciário foram ampliadas no CPC/2015, que incluiu expressamente os emolumentos extrajudiciais no conceito de justiça gratuita. Entretanto, o $\S 8^{\circ}$ do art. $98 \mathrm{CPC} / 2015$ determinou que o juízo competente para revogar a concessão de tal gratuidade seria o juízo competente para decidir questões notariais ou registrais, que é o juízo administrativo, diretor do foro, em regra. O problema que se apresenta: é o juízo administrativo competente para revogar decisão jurisdicional? A hipótese é que a justiça gratuita será concedida e revogada pelo próprio juiz da causa em respeito ao sistema uno de controle judicial.

PALAVRAS-CHAVE: Gratuidade; Emolumentos; Revisão; Administrativo; Judiciário.

ABSTRACT: Constitutional guarantees of access to the Judiciary were expanded in CPC/2015, which expressly included extrajudicial fees in the concept of free justice. However, $\S 8$ of art. $98 \mathrm{CPC} / 2015$ determined that the competent court to revoke the concession of such gratuity would be the competent court to decide notarial or registry issues, which is the administrative court, director of the forum, as a rule. The problem that 
Revista Eletrônica de Direito Processual - REDP.

Rio de Janeiro. Ano 15. Volume 22. Número 3. Setembro a Dezembro de 2021

Periódico Quadrimestral da Pós-Graduação Stricto Sensu em Direito Processual da UERJ

Patrono: José Carlos Barbosa Moreira (in mem.). ISSN 1982-7636. pp. 82-102

www.redp.uerj.br

arises: is the administrative court competent to revoke a jurisdictional decision? The hypothesis is that free justice will be granted and revoked by the judge of the case in respect of the unified system of judicial control.

KEYWORDS: Gratuity; Fees; Revision; Administrative; Judiciary.

\section{INTRODUÇÃO}

As garantias do acesso à jurisdição, bem como da assistência jurídica integral e gratuita, já consagradas constitucionalmente através do art. $5^{\circ}$, incisos XXXV e LXXIV da Constituição da República Federal do Brasil de 1988 (CRFB/1988) ganharam novos contornos com o art. 98 do Código Processo Civil Brasileiro de 2015 (CPC/15).

Não há dúvida que para efetivar direitos fundamentais garantidos constitucionalmente é necessário um sistema judiciário acessível inclusive aos hipossuficientes financeiramente. Não há dignidade garantida, tampouco justiça se não se possibilita efetivamente a cada um do povo a busca pelos seus direitos, sobretudo a busca pela defesa dos direitos fundamentais garantidos constitucionalmente.

A concessão do benefício da gratuidade da justiça está diretamente vinculado ao conceito de jurisdição e, também, à inafastabilidade da tutela jurisdicional, como instrumento de garantia de efetivação de direitos, valor muito caro que permeou todo código de processo civil de 2015, que primou pela garantia da solução de mérito e da sua efetividade.

Desta maneira, as custas processuais não podem impedir o acesso ao Poder Judiciário, tampouco o trâmite do procedimento judicial pode ser obstaculizado pela falta de recursos do cidadão para custear os honorários, as perícias e outros gastos financeiros. É preciso, portanto, reconhecer a importância do CPC/15, que trouxe previsão de instituto que garante possibilidade de acesso ao Poder Judiciário ainda que não se tenha condições financeiras.

Nesta ampliação de concessão de gratuidade, o art. 98 do CPC incluiu em seu $\S 1^{\circ}$, IX expressamente os emolumentos extrajudiciais no conceito de justiça gratuita. Assim, serão 
Revista Eletrônica de Direito Processual - REDP.

Rio de Janeiro. Ano 15. Volume 22. Número 3. Setembro a Dezembro de 2021

Periódico Quadrimestral da Pós-Graduação Stricto Sensu em Direito Processual da UERJ

Patrono: José Carlos Barbosa Moreira (in mem.). ISSN 1982-7636. pp. 82-102

www.redp.uerj.br

gratuitos os emolumentos devidos a notários ou registradores pelos atos de registro, averbação ou pela prática de ato notarial que se façam necessários para garantir a decisão judicial na qual o benefício tenha sido concedido. Entretanto, o $§ 8^{\circ}$ do art. $98 \mathrm{CPC} / 2015$ determinou que o juízo competente para revogar a concessão de tal gratuidade seria o juízo competente para decidir questões notariais ou registrais, que é o juízo administrativo, diretor do foro ou corregedor geral de justiça, em regra. O problema que se apresenta neste dispositivo: é o juízo administrativo competente para revogar decisão jurisdicional? A hipótese é que a justiça gratuita será concedida e revogada pelo próprio juiz da causa em respeito ao sistema uno de controle judicial.

Os objetivos deste artigo é apresentar o novo conceito de gratuidade constante do CPC/2015, suas hipóteses de concessão e revogação e o sistema de controle das decisões judiciais, seja administrativa ou jurisdicional, de modo a confrontar o sistema uno de controle adotado pelo Brasil com $\S 8^{\circ}$ do art. 98 , extraindo destas análise a interpretação do citado parágrafo. Para tanto, foram utilizadas na elaboração deste artigo o método jurídicoteórico e raciocínio dedutivo, com técnica de pesquisa bibliográfica. A pesquisa se justifica na medida que se faz necessário definir de quem é a competência para definir a definitividade da gratuidade concedida no âmbito do processo judicial, nos casos de requerimento de revogação da concessão para que não haja invasão de competência ou inversão da ordem estabelecida em um sistema uno de jurisdição, como o adotado pelo Brasil.

O desenvolvimento do artigo apresenta em sua primeira parte a conceituação dos institutos da gratuidade da justiça e da assistência judiciária gratuita, tendo como fundamento a Lei 1060/1950 e o art. 5. ${ }^{\circ}$, LXXIV da CRFB/1988, demonstrando a amplitude de cada um destes conceitos.

Após os estudos dos conceitos, será analisado o art. 98 do CPC/2015, especialmente o inciso IX e seus parágrafos, os quais criaram regras específicas para aplicação da gratuidade para os atos notariais e registrais, possibilitando inclusive a impugnação da concessão do benefício da justiça gratuita.

Considerando a existência de atividade administrativa atípica exercida pelo Poder Judiciário, especificamente no desempenho da funções de correição e no controle 
Revista Eletrônica de Direito Processual - REDP.

Rio de Janeiro. Ano 15. Volume 22. Número 3. Setembro a Dezembro de 2021

Periódico Quadrimestral da Pós-Graduação Stricto Sensu em Direito Processual da UERJ

Patrono: José Carlos Barbosa Moreira (in mem.). ISSN 1982-7636. pp. 82-102

www.redp.uerj.br

administrativo da atividades notarial e registral, apresentar-se-á na terceira parte deste artigo a repartição das funções exercidas pelos Poderes Judiciário, Executivo e Legislativo.

No próximo capítulo, será analisada os dois principais sistemas de controle de atos da Administração Pública judicial adotados no Ocidente, quais sejam; o sistema francês ou do contencioso administrativo e o sistema de jurisdição una ou inglês, apontando o adotado pelo ordenamento jurídico brasileiro e as implicações deste sistema para a conclusão deste trabalho.

Por fim, analisar-se-á a possibilidade das decisões de natureza jurisdicional serem revogadas pelo decisões judiciais de natureza administrativa, especialmente as decisões que deferiram o pedido de justiça gratuita.

\section{GRATUIDADE DA JUSTIÇA E ASSISTÊNCIA JUDICIÁRIA GRATUITA}

Inicialmente se faz necessário diferenciar os conceitos entre gratuidade de justiça e assistência judiciária gratuita, para evitar confusão conceitual comumente constatada na doutrina e jurisprudência.

A Lei 1.060/1950, que regula a assistência judiciária gratuita, prevê um sistema que garante a parte vulnerável economicamente o acesso à justiça, ainda que não tenha condições de arcar com os custos de um advogado, visando garantir um acesso judicial com efetiva assistência jurídica. ${ }^{1}$ Aqui há que se entender que o vulnerável economicamente não é somente o miserável, mas aquele que custeando o acesso à justiça possa violar a sua própria dignidade. Neste entendimento de hipossuficiente financeiro, Humberto Theodoro Júnior: "não é apenas o miserável, mas, assim, aquele com insuficiência de recursos para pagar as custas, despesas processuais e honorários advocatícios"2

Assim o Estado deve se estruturar para efetivar o patrocínio das causas dos economicamente necessitados, seja através de advogados mantidos pelo próprio Estado,

\footnotetext{
${ }^{1}$ BRASIL. Lei $n^{\circ}$ 1.060, de 5 de fevereiro de 1950. Presidência da República, Casa Civil, Subchefia para Assuntos Jurídicos. 1950.

2 JÚNIOR, Humberto Theodoro. Curso de Direito Processual Civil. 57 edição. Rio de Janeiro: Forense, 2016. V. I. Pág. 321.
} 
Revista Eletrônica de Direito Processual - REDP.

Rio de Janeiro. Ano 15. Volume 22. Número 3. Setembro a Dezembro de 2021

Periódico Quadrimestral da Pós-Graduação Stricto Sensu em Direito Processual da UERJ

Patrono: José Carlos Barbosa Moreira (in mem.). ISSN 1982-7636. pp. 82-102

www.redp.uerj.br

seja por indicação à Ordem dos Advogados, por suas Seções Estaduais, ou Subseções Municipais, seja por indicação de advogados de entidades privadas ou até mesmo particulares que o fazem voluntariamente. Neste sentido Gomes e Ferreira (2017, p. 102):

"No Estado Democrático de Direito, o povo é detentor do poder absoluto e, mediante sua insatisfação, vai defender seus direitos na espera do Poder Judiciário, e deste espera um provimento jurisdicional capaz de pôr fim ao conflito". ${ }^{3}$

Desta forma, a parte com insuficiência de recursos não ficará sem defensor em juízo, garantindo-lhe efetivamente o acesso à justiça para que se possa efetivar o princípio fundador do ordenamento jurídico brasileiro: a dignidade da pessoa humana. Carmen Lúcia Antunes Rocha (1999) ensina que dignidade é construção que se atrela a justiça. Segundo o autor: "a dignidade é mais um dado jurídico que uma construção acabada no Direito, porque se firma e se afirma no sentimento de justiça que domina o pensamento e a busca de cada povo em sua busca de realizar as suas vocações e necessidades". ${ }^{4}$

A dignidade da pessoa humana é a luz condutora de todos os ordenamentos jurídicos modernos e ao lado dela a implementação dos direitos fundamentais individuais e sociais, os quais efetivados garantirão a paz mundial e a justiça social resultando em uma civilização com maior equidade, com garantias que permitam diminuir a diferença entre ricos e pobres. Uma destas garantias é o acesso à justiça, considerando Mauro Cappelletti e Bryant Garth (1988), na década de setenta do século vinte, que o acesso à justiça é um movimento na primeira onda renovatória do acesso à ordem jurídica justa, das três ondas renovatórias identificadas pelos juristas acima citados. Segundo os autores: No sistema liberal, só quem tivesse capacidade para pagar os custos teriam acesso à justiça, deixando à própria sorte aqueles que não possuíssem recursos financeiros. Se garantia o acesso formal à justiça, mas não a efetiva prestação jurisdicional. ${ }^{5}$

Por isso, se faz necessária a completa e efetiva promoção dos direitos fundamentais, dentre eles o acesso a atividade jurisdicional a todos indistintamente.

3 GOMES, Magno Federici Gomes; FERREIRA, Leandro José. A dimensão jurídico-política da sustentabilidade e o direito fundamental à razoável duração do procedimento. In: Revista do Direito, 2017. v. 2, n. 52, p. 102.

${ }^{4}$ ROCHA. Cármen Lúcia Antunes. O Princípio da Dignidade da Pessoa Humana e a Exclusão Social. In: Revista Interesse Público, 1999. v. 4, n. 2.

${ }^{5}$ CAPPELlETTI, Mauro; GARHT, Bryan. Acesso à justiça. Porto Alegre: Fabris, 1988. p. 9. 
Revista Eletrônica de Direito Processual - REDP.

Rio de Janeiro. Ano 15. Volume 22. Número 3. Setembro a Dezembro de 2021

Periódico Quadrimestral da Pós-Graduação Stricto Sensu em Direito Processual da UERJ

Patrono: José Carlos Barbosa Moreira (in mem.). ISSN 1982-7636. pp. 82-102

www.redp.uerj.br

Neste sentido, e construindo o conceito de plexo de sustentabilidade:

Por isso, uma completa e precisa promoção dos direitos sociais fundamentais é indispensável para a implementação do plexo da sustentabilidade, com vistas a promover as bases da potencialidade humana com o objetivo de proclamar a justiça intergeracional da sobrevivência de longo prazo (GOMES; FERREIRA, 2018, p. 163). ${ }^{6}$

Da promulgação da Lei 1.060/1950, que regulou inicialmente a gratuidade da justiça, até a promulgação do CPC/15, que promoveu importantes revogações naquela, foram editadas outras normas que ampliaram o acesso à justiça, dentre elas a previsão na CRFB/1988, art. 5., LXXIV, que determinou: “o Estado prestará assistência jurídica integral e gratuita aos que comprovarem insuficiência de recursos". ${ }^{7}$ Dessa forma, tem-se a assistência judiciária gratuita, a justiça gratuita e a mais ampla de todas prevista na CRFB/1988, contida no artigo supramencionado: a assistência jurídica integral e gratuita.

A justiça gratuita possui alcance mais restrito que a assistência jurídica, pois compreende os gastos necessários que se faz em juízo para garantir o início e o andamento do feito, em todas as instâncias. Apesar de alcance mais restrito, a gratuidade é presumida, sendo esta uma novidade do CPC/2015 (art. 99, § 1. ${ }^{\circ}$ ) apontada por Fernanda Tartuce (2014), uma vez que que não é possível indeferimento de plano da gratuidade. ${ }^{8}$

Embora a doutrina não seja uníssona no alcance do conceito de custas judiciais, a "justiça gratuita", como ensina Marcacini (2009, p. 40) "compreende a isenção de toda e qualquer despesa necessária ao pleno exercício dos direitos e das faculdades processuais, sejam tais despesas judiciais ou não". Desta maneira, abrangerá todo e qualquer gasto para participação no processo, além das próprias custas dos atos processuais, mas também "todas as despesas decorrentes da efetiva participação na relação processual". 9

Portanto, em síntese, conclui-se que a assistência judiciária é o serviço de postulação em juízo e justiça gratuita é a isenção de custas e despesas. Por sua vez, assistência jurídica integral e gratuita são conjugações das duas anteriores e deve ser

6 GOMES, Magno Federici Gomes; FERREIRA, Leandro José. Políticas Públicas e os Objetivos do Desenvolvimento Sustentável. In: Revista de Direito e Desenvolvimento, 2018. v. 9, n. 2, p. 163.

${ }^{7}$ BRASIL. Constituição da República Federativa do Brasil de 1988. Presidência da República, Casa Civil, Subchefia para Assuntos Jurídicos. 1988.

8 TARTUCE, Fernanda: DELLORI, Luiz. Gratuidade da Justiça no Novo CPC. Revista de Processo, vol. 236, 2014, p. 305.

${ }^{9}$ MARCACINI, Augusto Tavares Rosa. Assistência jurídica e justiça gratuita. In: Associação Nacional das Defensoras e Defensores Pública, 2009. 
Revista Eletrônica de Direito Processual - REDP.

Rio de Janeiro. Ano 15. Volume 22. Número 3. Setembro a Dezembro de 2021

Periódico Quadrimestral da Pós-Graduação Stricto Sensu em Direito Processual da UERJ

Patrono: José Carlos Barbosa Moreira (in mem.). ISSN 1982-7636. pp. 82-102

www.redp.uerj.br

entendida como uma ampla proteção. Todavia, assim como o direito de acesso à Justiça não se limita ao Poder Judiciário, o direito de assistência jurídica integral e gratuita também não fica restrito ao âmbito judicial. Assim, assistência jurídica integral e gratuita é princípio amplo que protege e orienta os necessitados, nas palavras de Cassio Scarpinella Bueno (2015): “o princípio da assistência jurídica integral e gratuita vai além do acesso à Justiça e à ordem jurídica justa no sentido jurisdicional do termo, ao estabelecer como obrigação do Estado fora do plano do processo [...] resguardando e orientando os hipossuficientes". ${ }^{10}$

O CPC/15 contempla o instituto da gratuidade em diversos artigos, esclarecendo hipóteses de cabimento e até mesmo encerrando discussões a respeito de determinados gastos, na busca da promoção de uma tutela efetiva, adequada e tempestiva. Assim, haverá a entrega da solução para as partes efetivando o direito material por meio do processo. Nas palavras de Marinoni, Arenhart e Mitidiero (2019): “Tudo isto significa, ademais, que o processo reage ao direito. Vale dizer: que o plano do direito processual reage ao plano do direito material." "11

A grande inovação do $\mathrm{CPC} / 15$ em relação à gratuidade, foi a criação de uma seção inteira a número IV (Da gratuidade da Justiça), dentro do Título I (Das Partes e dos Procuradores), inserido no Livro III (Dos Sujeitos do Processo), só para tratar do assunto, demonstrando a preocupação com a busca da efetividade da tutela jurisdicional.

Uma destas discussões, até então, era se os emolumentos devidos a notários ou registradores estariam abarcados pelo conceito de gratuidade de justiça. A ausência de previsão expressa na Lei $\mathrm{n}^{\circ}$ 8.935, de 18 de novembro de 1994, que regulamenta o art. 236 da CRFB/1988, ${ }^{12}$ dispondo sobre serviços notariais e de registros criava dúvidas para a extensão deste benefício legal aos usuários dos serviços registrais e notariais. A Lei $\mathrm{n}^{\circ}$

${ }^{10}$ BUENO, Cassio Scarpinella. Manual de direito processual civil: inteiramente estruturado à luz do novo CPC - Lei n ${ }^{\circ}$ 13.105/15. São Paulo: Saraiva, 2015. p. 46.

${ }^{11}$ MARINONI, Luiz Guilherme; ARENHART, Sérgio Cruz; MITIDIERO, Daniel. Novo Código de processo civil comentado. 4. ed. rev. atual. e ampl. São Paulo: Revista dos Tribunais, 2019, p. 6.

12 Art. 236: "Os serviços notariais e de registro são exercidos em caráter privado, por delegação do Poder Público. $\S 1^{\circ}$ Lei regulará as atividades, disciplinará a responsabilidade civil e criminal dos notários, dos oficiais de registro e de seus prepostos, e definirá a fiscalização de seus atos pelo Poder Judiciário" (BRASIL, 1988). 
Revista Eletrônica de Direito Processual - REDP.

Rio de Janeiro. Ano 15. Volume 22. Número 3. Setembro a Dezembro de 2021

Periódico Quadrimestral da Pós-Graduação Stricto Sensu em Direito Processual da UERJ

Patrono: José Carlos Barbosa Moreira (in mem.). ISSN 1982-7636. pp. 82-102

www.redp.uerj.br

8.935/94, dispõe em seu art. $37^{13}$, que a fiscalização judiciária dos notários e registradores é matéria definida na esfera estadual ou do Distrito Federal. ${ }^{14}$

Por sua vez, o art. 103, da Constituição do Estado de Minas Gerais determina que compete privativamente:

I - aos tribunais de segundo grau:

a) eleger seus órgãos diretivos e elaborar seus regimentos internos com observância das normas de processo e das garantias processuais das partes e dispondo sobre a competência e o funcionamento dos respectivos órgãos jurisdicionais e administrativos;

b) organizar suas secretarias, seus serviços auxiliares e os dos juízos que lhes forem vinculados, velando pelo exercício da atividade correicional respectiva. ${ }^{15}$

A Lei Complementar $n^{\circ}$ 59, de 18 de janeiro de 2001, de Minas Gerais que dispõe sobre a organização e a divisão judiciária do Estado de Minas Gerais, determina no inciso XL do artigo 55 que compete ao Juiz de Direito exercer a fiscalização dos atos dos notários, dos oficiais de registro e dos seus prepostos, na forma da lei que lhes regula as atividades, e disciplinar as responsabilidades. ${ }^{16}$

Especificando os emolumentos mineiros, a Lei $\mathrm{n}^{\mathrm{o}} 15.524$, de 30 de dezembro de 2004, que dispõe sobre os valores dos Emolumentos e sobre a Taxa de Fiscalização Judiciária, determina no $\S 1^{\circ}$ do art. 20 que a concessão da isenção de emolumentos extrajudiciais fica condicionada a pedido formulado pela parte perante o oficial, no qual conste a sua expressa declaração de que é pobre no sentido legal e de que não pagou honorários advocatícios, para fins de comprovação junto ao Fisco Estadual e, na hipótese de constatação da improcedência da situação de pobreza, poderá o notário ou registrador exigir da parte o pagamento dos emolumentos e da Taxa de Fiscalização Judiciária correspondentes. ${ }^{17}$

\footnotetext{
${ }^{13}$ Art. 37: "A fiscalização judiciária dos atos notariais e de registro, mencionados nos artigos $6^{\circ}$ a $13^{\circ}$, será exercida pelo juízo competente, assim definido na órbita estadual e do Distrito Federal, sempre que necessário, ou mediante representação de qualquer interessado, quando da inobservância de obrigação legal por parte de notário ou de oficial de registro, ou de seus prepostos" (BRASIL, 1994).

${ }^{14}$ BRASIL. Artigo 37 da Lei $n^{o} 8.935$ de 18 de novembro de 1994. Jusbrasil, 1994.

${ }^{15}$ MINAS GERAIS. Constituição do Estado de Minas Gerais, Assembleia Legislativa de Minas Gerais, 1989.

${ }^{16}$ MINAS GERAIS. Lei complementar $n^{\circ} 59$ de 18 de janeiro de 2001. Assembleia Legislativa de Minas Gerais. 2001.

${ }^{17}$ MINAS GERAIS. Lei $n^{o} 15.424$, de 30 de dezembro de 2004. Secretaria de Estado de Fazenda de Minas Gerais. 2004.
} 
Revista Eletrônica de Direito Processual - REDP.

Rio de Janeiro. Ano 15. Volume 22. Número 3. Setembro a Dezembro de 2021

Periódico Quadrimestral da Pós-Graduação Stricto Sensu em Direito Processual da UERJ

Patrono: José Carlos Barbosa Moreira (in mem.). ISSN 1982-7636. pp. 82-102

www.redp.uerj.br

Entretanto, a despeito das normas contidas na Lei mineira $\mathrm{n}^{\circ} 15.524$, de 30 de dezembro de 2004, que trata dos emolumentos extrajudiciais, o Superior Tribunal de Justiça (STJ) já vinha há muito tempo entendendo que a gratuidade da justiça estende-se aos atos extrajudiciais relacionados à efetividade do processo judicial em curso, mesmo em se tratando de registro imobiliário. Segundo aquele Tribunal, a isenção contida no art. $3^{\circ}$, II, da Lei $\mathrm{n}^{\mathrm{o}}$ 1.060/50 estende-se aos valores devidos pela extração de certidões de registro de imóveis, necessárias ao exercício do direito de ação. ${ }^{18}$ Entretanto, desde 2015 a controvérsia foi sanada, uma vez que a previsão normativa do art. 98, parágrafo $1^{\circ}$, inciso IX do CPC/15 não deixa dúvidas. O direito à gratuidade da justiça compreende os emolumentos devidos a notários ou registradores em decorrência da prática de registro, averbação ou qualquer outro ato notarial necessário à efetivação de decisão judicial ou à continuidade de processo judicial no qual o benefício tenha sido concedido.

Porém, cessou-se uma discussão abriu-se outra, com base no $\S 8^{\circ}$ do art. 98 do $\mathrm{CPC} / 15 .{ }^{19} \mathrm{O}$ notário e registrador extrajudicial deverá praticar o ato, mesmo havendo dúvida do preenchimento dos pressupostos da concessão da gratuidade dos emolumentos e somente após requerer ao juízo competente para resolver questões notariais e registrais, que poderá decidir a revogação do benefício. A questão é: quem é o juízo competente se já houve decisão jurisdicional concedendo o benefício?

Para melhor compreensão da competência dos juízos, é necessário revisitar o conceito da separação das funções, bem como do controle da administração.

\section{SEPARAÇÃO DOS PODERES DO ESTADO}

O Estado, pessoa jurídica formada pelos elementos povo, território e soberania, deve se organizar de forma a atingir o bem geral da sociedade. Visando atingir seus

\footnotetext{
18 BRASIL. Recurso Ordinário em Mandado de Segurança 26493/RS 313060/SP. Superior Tribunal de Justiça (2. Turma), Ministra Relatora Eliana Calmon, DJe 23/09/2008, 2008.

19 Art $98 \S 8$ : : "Na hipótese do $\S 1$ 1, inciso IX, havendo dúvida fundada quanto ao preenchimento atual dos pressupostos para a concessão de gratuidade, o notário ou registrador, após praticar o ato, pode requerer, ao juízo competente para decidir questões notariais ou registrais, a revogação total ou parcial do benefício ou a sua substituição pelo parcelamento de que trata o $\S 6^{0}$ deste artigo, caso em que o beneficiário será citado para, em 15 (quinze) dias, manifestar-se sobre esse requerimento" (BRASIL, 2015).
} 
Revista Eletrônica de Direito Processual - REDP.

Rio de Janeiro. Ano 15. Volume 22. Número 3. Setembro a Dezembro de 2021

Periódico Quadrimestral da Pós-Graduação Stricto Sensu em Direito Processual da UERJ

Patrono: José Carlos Barbosa Moreira (in mem.). ISSN 1982-7636. pp. 82-102

www.redp.uerj.br

objetivos e maximizar os resultados, é preciso que as funções exercidas pelo Estado sejam divididas.

De acordo com Alexandrino (2011), a existência da repartição de poderes consiste na pedra fundamental do Estado, seja Federado ou Unitário. O autor ensina que a organização política do Estado é integrada pelos poderes, os quais representam um divisão interna, que evita a concentração de poderes e especializa as funções. ${ }^{20}$

Assim, tal qual idealizado, o Poder Legislativo elabora as leis, determinando as normas gerais de conduta, regulando os direitos individuais e os direitos do próprio Estado.

Por sua vez, o Poder Executivo deverá executar as leis formuladas pelo Poder Legislativo, administrando os interesses públicos, cumprindo fielmente as ordenações legais.

Finalmente, ao Poder Judiciário é atribuída a função de administração da Justiça na sociedade, através da físcalização do cumprimento de normas jurídicas. O Poder Judiciário, guardião da CRFB/1988, deve assegurar a coexistência harmônica de todos os poderes, de forma a garantir a autonomia, porém revendo atos dos outros poderes. De acordo com Maluf (2017, p. 217), trata-se, pois, de uma "divisão funcional do poder de soberania em três órgãos, pelos quais ela se manifesta em sua amplitude". ${ }^{21}$

Estaria assim instituído o sistema de controles recíprocos das funções de elaborar leis, executá-las e fiscalizar o devido cumprimento do sistema jurídico. Silva (2016) destaca que:

A harmonia entre os poderes verifica-se primeiramente pelas normas de cortesia no trato recíproco e no respeito às prerrogativas e faculdades a que mutuamente todos têm direito. De outro lado, cabe assinalar que nem a divisão de funções entre os órgãos do poder nem a sua independência são absolutas. Há interferências, que visam ao estabelecimento de um sistema de freios e contrapesos, à busca do equilíbrio necessário à realização do bem da coletividade e indispensável para evitar o arbítrio e o demando de um em detrimento do outro e especialmente dos governados (SILVA, 2016, p. 109). ${ }^{22}$

${ }^{20}$ ALEXANDRINO, Marcelo. Direito administrativo descomplicado. 19. Ed. Ver. e atual. São Paulo: Método, 2011.

${ }^{21}$ MALUF S, Teoria Geral do Estado, Ed. Saraiva, São Paulo, 2017, p. 217.

${ }^{22}$ SILVA, José Afonso da. Curso de Direito Constitucional Positivo. 39. Ed. São Paulo: Malheiros, 2016 
Revista Eletrônica de Direito Processual - REDP.

Rio de Janeiro. Ano 15. Volume 22. Número 3. Setembro a Dezembro de 2021

Periódico Quadrimestral da Pós-Graduação Stricto Sensu em Direito Processual da UERJ

Patrono: José Carlos Barbosa Moreira (in mem.). ISSN 1982-7636. pp. 82-102

www.redp.uerj.br

Desta forma, o Brasil organizou-se com base no sistema da teoria da separação dos três poderes idealizado por Montesquieu, segundo o qual o Estado, para exercer sua autonomia, deveria dividir seus poderes, oferecer competência e autonomia a cada um deles. Seguiu o Brasil os ensinamentos da revolução francesa, que proclamou que a separação dos poderes e os direitos fundamentais formam a pedra fundamental para a sociedade constitucionalista, ensinamentos estes inseridos na Declaração dos Direitos do Homem e do Cidadão de 1789. Desde a Constituição de 1824, o Brasil recém independente adota a divisão dos poderes.

Tornando-nos para o século XXI, determina a CRFB/1988 em seu art. $2^{\circ}$ que os Poderes da União serão o Legislativo, o Executivo e o Judiciário. Nesta divisão tripartite todos os poderes serão independentes e harmônicos entre si. O exercício das funções será desempenhado de forma colaborativa e harmônica, sempre visando o fim comum que é interesse público. Entretanto as funções são independentes, podendo se auto-organizarem, possuindo finanças próprias e regras específicas de funcionamento. ${ }^{23}$

Ao princípio da separação dos poderes, foi constitucionalmente dado em 1988, natureza de cláusula pétrea, não podendo ser alterado nem mesmo por ementa constitucional.

Com a evolução do constitucionalismo, a divisão rígida foi sendo flexibilizada, permitido que os poderes exerçam também funções atípicas. Assim, o Judiciário e o Legislativo exercem funções administrativas, quando por exemplo, gerenciam seus serviços, pessoal e material. Aqui cabe ressaltar que o Judiciário exerce esta função administrativa quando gerencia seus órgãos e serviços, a exemplo dos extrajudiciais, nos quais se encontram os registrais e notariais. Desta forma, quando houver dúvidas dos registradores e notários, elas serão solucionadas pelos juízes competentes na matéria, conforme organização estadual, mas sem retirar o caráter administrativo.

\section{SISTEMAS DE CONTROLE DA ADMINISTRAÇÃO PÚBLICA}

\footnotetext{
${ }^{23}$ BRASIL. Constituição da República Federativa do Brasil de 1988. Presidência da República, Casa Civil, Subchefia para Assuntos Jurídicos. 1988.
} 
Revista Eletrônica de Direito Processual - REDP.

Rio de Janeiro. Ano 15. Volume 22. Número 3. Setembro a Dezembro de 2021

Periódico Quadrimestral da Pós-Graduação Stricto Sensu em Direito Processual da UERJ

Patrono: José Carlos Barbosa Moreira (in mem.). ISSN 1982-7636. pp. 82-102

www.redp.uerj.br

Inicialmente é necessário definir o que é um sistema de controle da Administração Pública. Trata-se do regime adotado pelo Estado para controlar a legalidade dos atos praticados por seus agentes em todos os níveis de governo. De acordo com Di Pietro (2017), o controle judicial e o princípio da legalidade constituem os fundamentos do Estado de Direito. ${ }^{24}$ Existem basicamente dois sistemas: o Francês e o Inglês.

O sistema francês, ou do Contencioso Administrativo, analisa com exclusividade todos os atos administrativos de forma definitiva. Há neste sistema uma absoluta separação dos poderes. Não há possibilidade de nova discussão judicial a respeito de matérias e situações já decididas pelos órgãos do Contencioso Administrativo através de seu órgão máximo, o Conselho do Estado. Este sistema é independente do Sistema Judicial e os atos da Administração Pública submetidos a julgamento pelo Conselho de Estado, órgão especialmente criado para este fim, terão definitividade das decisões proferidas.

A Revolução Francesa alçou ao poder uma nova classe que passou a administrar o Estado com novas ideias e regras sociais diferentes, o que foi alvo de resistência, ensejando então a criação de suporte administrativo que mantivesse as reformas recentes efetivadas pelos novos administradores, criando-se a dualidade de jurisdição. Sobre o sistema francês Meirelles (2004) explica que:

A Revolução (1789), imbuída de liberalismo e ciosa da independência
dos Poderes, regrada por Montesquieu, encontrou ambiente propício para
separar a Justiça Comum da Administração, com o quê atendeu não só ao
desejo de seus doutrinadores como aos anseios do povo já descrente da
ingerência judiciária nos negócios do Estado. Separam-se os poderes. E
extremando os rigores dessa separação, a Lei 16, de 24.8 .1790 , dispôs:
"As funções judiciárias são distintas e permanecerão separadas das
funções administrativas. Não poderão os juízes, sob pena de
prevaricação, perturbar, de qualquer maneira, as atividades dos corpos
administrativos (MEIRELLES, 2004, p. 53). ${ }^{25}$

No sistema francês existe uma dualidade de jurisdição. Existe um Tribunal para decidir definitivamente a respeito de questões administrativas e sobre lides em que Administração Pública participe, e outro para decidir as demais questões. Neste sistema existe uma especialização dos julgadores que são conhecedores em profundidade do

\footnotetext{
${ }^{24}$ DI PIETRO, Maria Syvia Zanella. Direito Administrativo. 30. Ed. São Paulo: Forense, 2017.

${ }^{25}$ MEIRELLES, Hely Lopes. Direito Administrativo Brasileiro. São Paulo: Malheiros Editores, 2004.
} 
Revista Eletrônica de Direito Processual - REDP.

Rio de Janeiro. Ano 15. Volume 22. Número 3. Setembro a Dezembro de 2021

Periódico Quadrimestral da Pós-Graduação Stricto Sensu em Direito Processual da UERJ

Patrono: José Carlos Barbosa Moreira (in mem.). ISSN 1982-7636. pp. 82-102

www.redp.uerj.br

Direito administrativo, produzindo decisões eminentemente técnicas, uma vez que são escolhidos pela amplitude de conhecimento acerca dos conflitos da Administração.

Por outro lado, temos o sistema de jurisdição, no qual todas as questões serão decididas de forma definitiva apenas pelo Poder Judiciário, tenham ou não as matérias sido decididas administrativamente, não adentrando, todavia, no mérito da questão. Examina-se a legalidade e legitimidade dos atos. Modernamente admite-se até o exame do mérito, utilizando-se dos princípios da razoabilidade e da proporcionalidade para consecução do fim social.

O ordenamento jurídico pátrio adotou o sistema anglo-saxão, de jurisdição una, sendo que os atos administrativos sempre podem ser analisados e revistos pelo Poder Judiciário, que finaliza os conflitos com decisões definitivas. Assim, somente as decisões proferidas pelo Judiciário formam coisa julgada e possuem definitividade. Embora, os Tribunais administrativos existam no Brasil, a exemplo do Conselho Administrativo de Recursos Fiscais (CARF), órgão que julga os recursos dos contribuintes tributários em matéria federal, sempre poderão ter suas decisões alteradas pelos juízes. Neste sistema há Jurisdição una e por determinação expressa do art. $5^{\circ}$, inciso XXXV, da CRFB/1988, todos poderão se socorrer do Poder Judiciário ao dispor que a lei não excluirá da apreciação do Poder Judiciário lesão ou ameaça a direito.

Neste contexto jurídico, toda decisão administrativa está sujeita a reforma perante o Poder Judiciário.

\section{REVISÃO DAS DECISÕES ADMINISTRATIVAS PELO JUDICIÁRIO}

Vê-se que pelo sistema de controle adotado pelo Brasil, as decisões, qualquer que sejam sua natureza, poderão ser revistas pelo Poder Judiciário. Assim, as decisões dos juízes que atuam na atividade de correição dos serviços extrajudiciais, dentre eles os registrais e notariais, são de natureza administrativa e, portanto, podem ser revistas pelo Poder Judiciário na sua função jurisdicional. Neste entendimento, Kumpel (2016) observa que:

Muito embora a atividade de correição seja exercida por juízes de direito, não se trata de exercício da função jurisdicional. Trata-se, em verdade, de 
Revista Eletrônica de Direito Processual - REDP.

Rio de Janeiro. Ano 15. Volume 22. Número 3. Setembro a Dezembro de 2021

Periódico Quadrimestral da Pós-Graduação Stricto Sensu em Direito Processual da UERJ

Patrono: José Carlos Barbosa Moreira (in mem.). ISSN 1982-7636. pp. 82-102

www.redp.uerj.br

atividade judicial de natureza administrativa. Os juízes corregedores permanentes são a longa manus do Corregedor Geral da Justiça no controle administrativo-funcional da atividade notarial e registral (KUMPEL, 2016, p. 4). ${ }^{26}$

Por ser o sistema brasileiro uno de jurisdição e sendo as decisões dos juízes que atuam na atividade de correição dos serviços extrajudiciais de natureza administrativa, jamais poderiam estas alterar aquelas sob pena de subversão de todo o nosso sistema e criação de situações teratológicas, como a situação da parte que, descontente com a decisão administrativa que revoga o benefício concedido jurisdicionalmente, poder voltar ao Poder Judiciário, transformando a situação num círculo sem fim. Esta é também a pergunta posta por Kumpel (2016):

Ora, como é possível que o juiz, no exercício de atividade administrativa, possa rever decisão jurisdicional? Como seria possível uma decisão jurisdicional determinada ou não modificada pelo Superior Tribunal de Justiça, por exemplo, ser alterada por um juiz no exercício de atividade administrativa? Evidente que a norma em questão subverte o conceito ontológico do sistema. A decisão administrativa é que sempre deve ser revista pelo viés jurisdicional, e nunca o sentido contrário (KUMPEL, 2016, p. 4). ${ }^{27}$

Também é entendimento firmado pela Corregedoria Geral da Justiça de São Paulo e pelo Conselho Superior da Magistratura, qual seja, a via administrativa não pode rever decisões oriundas da via jurisdicional tribunais, conforme se pode verificar na decisão na Apelação Cível, de 10 de março de 2015, - DJ nº 0006128-03.2012.8.26.0362:

Registro de Imóveis - Arrolamento de Bens - Carta de Adjudicação Recusa do registro em razão da exclusão de herdeiro em relação à universalidade dos bens deixados - Questão que desborda dos limites da qualificação registral - Impossibilidade de discutir na via administrativa o mérito da decisão judicial transitada em julgado - Recusa afastada Recurso provido. ${ }^{28}$

Por outro lado, pode-se fazer uma interpretação do $\S 8^{\circ}$ do art. 98 CPC/2015 de que o juízo competente ali referido depende da circunstância da concessão do benefício legal. Se foi através do Poder Judiciário, será o juiz da causa o competente para decidir. Assim entende Pedroso e Bartini (2016):

\footnotetext{
${ }^{26}$ KUMPEL, Frederico Victor. O art. 98, § 8o, do novo CPC e a impossibilidade da revisão de decisão de natureza jurisdicional pelo juízo administrativo. In: Migalhas. São Paulo, 28 de jun. 2016.

${ }^{27}$ KUMPEL, Frederico Victor. O art. 98, § 8o, do novo CPC e a impossibilidade da revisão de decisão de natureza jurisdicional pelo juízo administrativo. In: Migalhas. São Paulo, 28 de jun. 2016.

${ }^{28}$ TRIBUNAL DE JUSTIÇA DE SÃO PAULO. Apelação: APL 0006128-03.2012.8.26.0362 SP 000612803.2012.8.26.0362 - Inteiro Teor, 2015.
} 
Revista Eletrônica de Direito Processual - REDP.

Rio de Janeiro. Ano 15. Volume 22. Número 3. Setembro a Dezembro de 2021

Periódico Quadrimestral da Pós-Graduação Stricto Sensu em Direito Processual da UERJ

Patrono: José Carlos Barbosa Moreira (in mem.). ISSN 1982-7636. pp. 82-102

www.redp.uerj.br

Competência para apreciação do pedido impugnativo do tabelião ou registrador, ou seja, melhor interpretação da expressão "juízo competente para decidir questões notariais ou registrais": tratando de benesse legal conferida na esfera jurisdicional pelo juiz do processo, entendemos que o pedido impugnativo apresentado pelo tabelião ou registrador deverá ser encaminhado e apreciado pelo magistrado que conduz o processo judicial e não pelo juiz corregedor permanente (PEDROSO; BARTINI, 2016, p. 4). ${ }^{29}$

Utilizando o método de interpretação sistemática, o qual analisa as normas jurídicas entre si, pressupondo que o ordenamento é um todo unitário, sem incompatibilidades, o que permite escolher o significado da norma que seja coerente com o conjunto, verifica-se que a hipótese $\S 8^{\circ}$ do art. $98 \mathrm{CPC} / 2015$ poderá ser aplicado quando o benefício for requerido no próprio Serviço de Registro ou de Notas. Caso o registrador ou tabelião tenha dúvida fundada quanto ao preenchimento atual dos pressupostos para a concessão de gratuidade ele pode requerer ao "juízo competente para decidir questões notariais ou registrais" (BRASIL, 1988), a revogação do benefício, uma vez que já teria praticado o ato, por ordem do próprio art. 98 do $\mathrm{CPC} / 15$.

Ademais, o usuário pode requerer alguns serviços nas serventias extrajudiciais sob o pálio da justiça gratuita por expressa disposição legal, a exemplo das demais certidões de nascimento e de óbito para os declaradamente pobres, conforme determina a lei 9534/1997 que alterou artigos da Lei de Registros Públicos (Lei 6015/73) e da Lei 8935/94. Salientese que o registro e a primeira certidão de nascimento e de óbito são gratuitos sem nenhuma exigência de declaração de pobreza. Entretanto nos casos em que exige a declaração de pobreza, o próprio tabelião ou registrador poderá solicitar a apresentação de documentos que comprovem os termos da declaração. Desta forma, diante dos documentos apresentados se o delegatário não concordar com alegação de pobreza pode exigir o pagamento dos emolumentos. Ademais, o próprio tabelião ou registrador poderá impugnar o pedido de isenção junto ao Juiz Diretor do Foro. Neste entendimento, o artigo 140 do Provimento Conjunto Nr 93/2020/PR/CGJ/MG:

Art. 140. Para a obtenção de isenção do pagamento de emolumentos e da TFJ, nas hipóteses previstas em lei, a parte apresentará pedido em que conste expressamente a declaração de que é pobre no sentido legal, sob as penas da lei.

\footnotetext{
${ }^{29}$ PEDROSO, Alberto Gentil de Almeida; BARTINI, Caio. A incidência da gratuidade da justiça para os emolumentos: possibilidade e procedimento pelo Novo Código de Processo civil. 2016.
} 
Revista Eletrônica de Direito Processual - REDP.

Rio de Janeiro. Ano 15. Volume 22. Número 3. Setembro a Dezembro de 2021

Periódico Quadrimestral da Pós-Graduação Stricto Sensu em Direito Processual da UERJ

Patrono: José Carlos Barbosa Moreira (in mem.). ISSN 1982-7636. pp. 82-102

www.redp.uerj.br

$\S 1^{\circ} \mathrm{O}$ tabelião e o oficial de registro poderão solicitar a apresentação de documentos que comprovem os termos da declaração.

$\S 2^{\circ}$ Não concordando com a alegação de pobreza, o tabelião ou oficial de registro poderá exigir da parte o pagamento dos emolumentos e da TFJ correspondentes.

$\S 3^{\circ}$ No caso de recusa do pagamento e não estando o tabelião ou oficial de registro convencido da situação de pobreza declarada, poderá impugnar o pedido perante o diretor do foro, observado o procedimento previsto nos arts. 150 a 161 deste Provimento Conjunto. ${ }^{30}$

Portanto, restam algumas possiblidades para a aplicação do $\S 8^{\circ}$ do art. $98 \mathrm{CPC} / 15$, as quais ainda não foram devidamente discutidas no âmbito dos Tribunais e da doutrina especializada.

Por fim, ainda resta saber de quem é o ônus da prova relativa à hipossuficiência financeira da parte, que não raro apresenta o mandado judicial para registro ou averbação muito tempo depois do trânsito em julgado da sentença, às vezes anos se passam entre a decisão e o requerimento do usuário para a prática do ato notarial e registral. Exemplo desta situação ocorre comumente nas sentenças de divórcio, que não são levadas imediatamente para averbação no registro de casamento, sendo requerido o ato somente em situação de necessidade subsequente, como em inventários e morte. Assim, a situação financeira pode inclusive ter se alterado ao longo do tempo.

Como determinado pelo artigo 99 em seu $\S 2^{\circ}$ do CPC/2015, a alegação pelas pessoas físicas de hipossuficiência é presumida. Portanto, o juiz só poderá indeferir o pedido, se houver nos autos elementos que evidenciam o contrário do pedido. Entretanto, fica a dúvida acerca do ônus da prova relativa à falta dos pressupostos da hipossuficiência, nos casos em que o tabelião ou registrador requeira a revogação do benefício da gratuidade. Seria do Tabelião/registrador ou seria do beneficiário da justiça gratuita demonstrar que ainda persiste a situação de hipossuficiência?

Analisando o artigo 373 do CPC, o qual distribui o ônus da prova, verifica-se que caberia ao impugnante provar o fato extintivo do direito. Por outro lado, segundo os artigos 99, $\S 2^{\circ}$ e $337, \S 5^{\circ}$ do CPC, esta questão seria de ordem pública e poderia ser decidida a qualquer momento pelo juízo, mormente considerando que a serventia extrajudicial exerce função de auxiliar do juízo.

\footnotetext{
${ }^{30}$ BRASIL. Provimento conjunto Nr 93/2020 PR/CGJ/MG. Corregedoria Geral de Justiça de Minas Gerais,
} 


\section{CONSIDERAÇÕES FINAIS}

As garantias do acesso à justiça bem como da assistência jurídica integral e gratuita, já consagradas constitucionalmente ganharam novos contornos com o art. 98 do CPC/15, que emergiu com valores caros como a força da primazia da decisão de mérito e sua efetividade. Certo é, que para garantir a efetividade da jurisdição a todos os cidadãos seriam necessários instrumentos que possibilitassem o acesso à jurisdição, independentemente da condição financeira de cada um, sob pena de inviabilizar a jurisdição aos hipossuficientes financeiros.

Nesta busca pelo acesso de todos ao Judiciário, a justiça gratuita foi expressa e minuciosamente detalhada no $\mathrm{CPC} / 2015$, relacionando cada uma das despesas, taxas, emolumentos, honorários que se compreendiam no conceito de justiça gratuita.

Assim, se existiam dúvidas acerca da inclusão dos emolumento extrajudiciais no conceito de justiça gratuita, desde 2015 foram sanadas, com a previsão normativa do art. 98, parágrafo $1^{\circ}$, inciso $\mathrm{IX}$ do $\mathrm{CPC} / 15$, que determinou que o direito à gratuidade da justiça compreende os emolumentos devidos a notários ou registradores em decorrência da prática de registro, averbação ou qualquer outro ato notarial necessário à efetivação de decisão judicial ou à continuidade de processo judicial no qual o benefício tenha sido concedido.

Entretanto, caso o registrador ou Tabelião tenha dúvida fundada quanto ao preenchimento atual dos pressupostos para a concessão de gratuidade, pode requerer, ao juízo competente, que decida acerca das questões notariais ou registrais, da revogação total ou parcial do benefício ou a sua substituição pelo parcelamento.

Conclui-se que o juízo competente constante do art. $98 \S 8^{\circ}$ do CPC/2015 é nos casos em que a prática do ato foi efetuado diretamente por pedido da parte no próprio serviço registral ou notarial, o Juiz Corregedor ou Diretor do foro por ser o competente para a administração e correição dos serviços auxiliares, considerando que as atividades registrais e notarias são serviços auxiliares do juízo.

Por outro lado, se a concessão do benefício foi deferida judicialmente, através das 
Revista Eletrônica de Direito Processual - REDP.

Rio de Janeiro. Ano 15. Volume 22. Número 3. Setembro a Dezembro de 2021

Periódico Quadrimestral da Pós-Graduação Stricto Sensu em Direito Processual da UERJ

Patrono: José Carlos Barbosa Moreira (in mem.). ISSN 1982-7636. pp. 82-102

www.redp.uerj.br

funções jurisdicionais, o juízo competente para decidir será o do caso concreto, sob pena de se inverter o sistema uno de jurisdição adotado pela CRFB/1988.

\section{REREFÊNCIAS}

ALEXANDRINO, Marcelo. Direito administrativo descomplicado. 19. Ed. Ver. e atual. São Paulo: Método, 2011.

BRASIL. Lei $n^{\circ}$ 1.060, de 5 de fevereiro de 1950. Presidência da República, Casa Civil, Subchefia para Assuntos Jurídicos. 1950.

BRASIL. Constituição da República Federativa do Brasil de 1988. Presidência da República, Casa Civil, Subchefia para Assuntos Jurídicos. 1988.

BRASIL. Artigo 37 da Lei $n^{o} 8.395$ de 18 de novembro de 1994. Jusbrasil, 1994.

BRASIL. Recurso Ordinário em Mandado de Segurança 26493/RS 313060/SP. Superior

Tribunal de Justiça (2. Turma), Ministra Relatora Eliana Calmon, DJe 23/09/2008, 2008 .

BRASIL. Artigo da Lei $n^{o} 13.105$ de 16 de março de 2015. Jusbrasil. 2015.

BRASIL. Provimento conjunto Nr 93/2020 PR/CGJ/MG. Corregedoria Geral de Justiça de Minas Gerais, 2020.

BUENO, Cassio Scarpinella. Manual de direito processual civil: inteiramente estruturado à luz do novo CPC - Lei no 13.105/15. São Paulo: Saraiva, 2015. p. 46.

CAPPELLETTI, Mauro; GARHT, Bryan. Acesso à justiça. Porto Alegre: Fabris, 1988. p. 9.

DI PIETRO, Maria Syvia Zanella. Direito Administrativo. 30. Ed. São Paulo: Forense, 2017.

GOMES, Magno Federici Gomes; FERREIRA, Leandro José. A dimensão jurídico-política da sustentabilidade e o direito fundamental à razoável duração do procedimento. In: Revista do Direito, 2017. v. 2, n. 52, p. 102.

GOMES, Magno Federici Gomes; FERREIRA, Leandro José. Políticas Públicas e os Objetivos do Desenvolvimento Sustentável. In: Revista de Direito e Desenvolvimento, 2018. v. 9, n. 2, p. 163. 
Revista Eletrônica de Direito Processual - REDP.

Rio de Janeiro. Ano 15. Volume 22. Número 3. Setembro a Dezembro de 2021

Periódico Quadrimestral da Pós-Graduação Stricto Sensu em Direito Processual da UERJ

Patrono: José Carlos Barbosa Moreira (in mem.). ISSN 1982-7636. pp. 82-102

www.redp.uerj.br

KUMPEL, Frederico Victor. O art. 98, § 8o, do novo CPC e a impossibilidade da revisão de decisão de natureza jurisdicional pelo juízo administrativo. In: Migalhas. São Paulo, 28 de jun. 2016. Disponível em: <https://www.migalhas.com.br/coluna/registralhas/239994/o-art--98----8o--do-novocpc-e-a-impossibilidade-da-revisao-de-decisao-de-natureza-jurisdicional-pelo-juizoadministrativo>. Acesso em: 30 jun. 2021.

MALUF, Sahid. Teoria Geral do Estado. 33 ed. São Paulo: Saraiva, 2017.

MARCACINI, Augusto Tavares Rosa. Assistência jurídica e justiça gratuita. In: Associação Nacional das Defensoras e Defensores Pública, 2009.

MARINONI, Luiz Guilherme; ARENHART, Sérgio Cruz; MITIDIERO, Daniel. Novo Código de processo civil comentado. 4. ed. rev. atual. e ampl. São Paulo: Revista dos Tribunais, 2019, p. 6.

MEIRELLES, Hely Lopes. Direito Administrativo Brasileiro. São Paulo: Malheiros Editores, 2004.

MINAS GERAIS. Constituição do Estado de Minas Gerais, Assembreia Legislativa de Minas Gerais, 1989.

MINAS GERAIS. Lei complementar $n^{o} 59$ de 18 de janeiro de 2001. Assembleia Legislativa de Minas Gerais. 2001

MINAS GERAIS. Lei $n^{\circ} 15.424$, de 30 de dezembro de 2004. Secretaria de Estado de Fazenda de Minas Gerais. 2004.

PEDROSO, Alberto Gentil de Almeida; BARTINI, Caio. A incidência da gratuidade da justiça para os emolumentos: possibilidade e procedimento pelo Novo Código de Processo civil. 2016. Disponível em: http://iregistradores.org.br/a-incidencia-dagratuidade-da-justica-para-os-emolumentos-possibilidade-e-procedimento-pelo-novocodigo-de-processo-civil-2/. Acesso em: 25 mar. 2017.

ROCHA. Cármen Lúcia Antunes. O Princípio da Dignidade da Pessoa Humana e a Exclusão Social. In: Revista Interesse Público, 1999. v. 4, n. 2, p. 23-48.

STRECK, Lênio Luiz; CUNHA, Leonardo Carneiro da; NUNES, Dierle. Comentários ao Código de Processo Civil. São Paulo: Saraiva, 2017.

TARTUCE, Fernanda: DELLORI, Luiz. Gratuidade da Justiça no Novo CPC. Revista de 
Revista Eletrônica de Direito Processual - REDP.

Rio de Janeiro. Ano 15. Volume 22. Número 3. Setembro a Dezembro de 2021

Periódico Quadrimestral da Pós-Graduação Stricto Sensu em Direito Processual da UERJ

Patrono: José Carlos Barbosa Moreira (in mem.). ISSN 1982-7636. pp. 82-102

www.redp.uerj.br

Processo, vol. 236, 2014, p. 305.

THEODORO JUNIOR, Humberto. Curso de Direito Processual Civil. 57 edição. Rio de Janeiro: Forense, 2016. V. I. Pág. 321.

TRIBUNAL DE JUSTIÇA DE SÃO PAULO. Apelação: APL 0006128-03.2012.8.26.0362 SP 0006128-03.2012.8.26.0362 - Inteiro Teor, 2015. 